\title{
Review on Friction Stir Processed TIG and Friction Stir Welded Dissimilar Alloy Joints
}

\author{
Sipokazi Mabuwa *(-) and Velaphi Msomi 1 \\ Faculty of Engineering and the Built Environment, Cape Peninsula University of Technology, P.O. Box 1906, \\ Bellville 7535, South Africa; msomiv@gmail.com \\ * Correspondence: sipokazimabuwa@gmail.com; Tel.: +27-219538778
}

Received: 18 October 2019; Accepted: 10 December 2019; Published: 17 January 2020

\begin{abstract}
There is an increase in reducing the weight of structures through the use of aluminium alloys in different industries like aerospace, automotive, etc. This growing interest will lead towards using dissimilar aluminium alloys which will require welding. Currently, tungsten inert gas welding and friction stir welding are the well-known techniques suitable for joining dissimilar aluminium alloys. The welding of dissimilar alloys has its own dynamics which impact on the quality of the weld. This then suggests that there should be a process which can be used to improve the welds of dissimilar alloys post their production. Friction stir processing is viewed as one of the techniques that could be used to improve the mechanical properties of a material. This paper reports on the status and the advancement of friction stir welding, tungsten inert gas welding and the friction stir processing technique. It further looks at the variation use of friction stir processing on tungsten inert gas and friction stir welded joints with the purpose of identifying the knowledge gap.
\end{abstract}

Keywords: friction stir welding; tungsten inert gas welding; friction stir processing; dissimilar aluminium alloys joints; dissimilar metal joints

\section{Introduction}

Aluminium alloys are known to be good candidates for different applications in various fields like aerospace, food packaging, automotive industries, etc. Their good candidacy came from the fact that these metals are light in weight, have good mechanical properties, good corrosion resistance, etc. Various aluminium alloys possess different mechanical and thermal properties and these differences are influenced by the alloying elements used in producing each alloy [1,2]. Most industries are opting towards using dissimilar alloys in producing various components. This option is meant to reduce the costs that are involved in using similar alloys [3]. In as much as this approach is a cost-saving measure, however, there are also challenges associated with it. This includes the welding technique suitable at welding dissimilar alloys. The most used welding techniques involve tungsten inert gas (TIG) welding and friction stir welding (FSW). The TIG welding technique has been dominant in joining similar and dissimilar aluminium alloys until the birth of FSW.

There have been some challenges that were involved in joining dissimilar alloys through TIG technique. Those challenges include porosity, solidification cracking, thermal residual stresses, etc. These challenges have led to the discovering of the post-processing technique called friction stir processing. Friction stir processing (FSP) is a technique used to modify the microstructure of a metal through the use of a non-consumable rotating tool. FSP originated from friction stir welding which was initially established by The Welding Institute. FSP uses the same principle as FSW but does not join metals rather modifies the local microstructure in the near-surface layer of metals [4]. Figure 1 shows the schematic diagram of FSP and FSW techniques. 


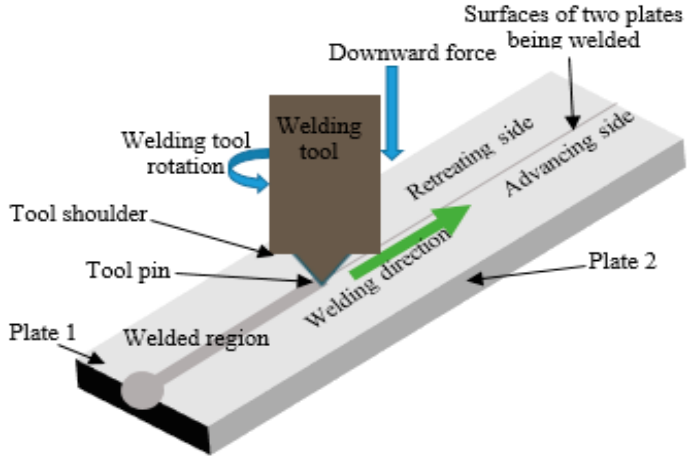

(a)

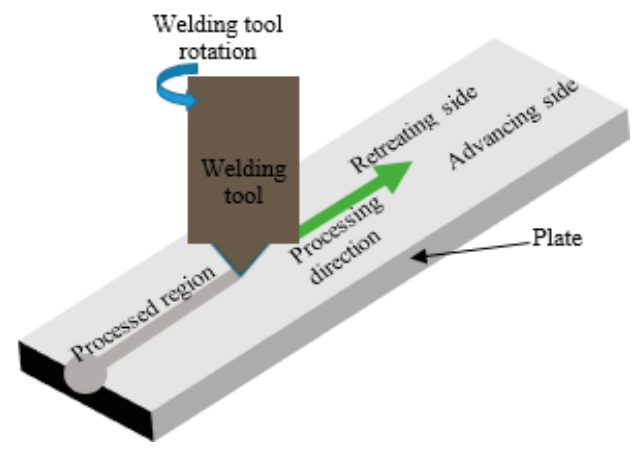

(b)

Figure 1. (a) FSW (friction stir welding) and (b) FSP (Friction stir processing) technique.

FSP works by plunging a specific cylindrical non-consumable tool into the plate and kept stationary for a few seconds. This is done so as to allow the stabilization in an input temperature required for processing. The rotating tool gets released so that it travels along the surface of the metal being processed. The tool travels from the start to the end of the plates resulting in the attainment of the processing. When the processing is finished, the tool is then unplunged, leaving a small hole, or rather travels to an offset distance to avoid leaving a hole. The side in which the tangential velocity of the tool surface is parallel to the traverse direction is called the advancing side, and the non-parallel side is called the retreating side $[5,6]$.

This paper is aiming at reviewing the works that deals with the processing of similar and dissimilar joints produced by the TIG and FSW welding techniques.

\section{Review on Friction Stir Welding, TIG Welding and Friction Stir Processing}

\subsection{Friction Stir Welding of Similar and Dissimilar Alloys}

Recent studies have revealed that the material positioning during FSW of dissimilar plays an important role towards the strength of the weld. The good weld is produced when the hardest material is positioned on the retreating side while keeping the softer one on the advancing side during welding $[7,8]$. In an attempt towards analyzing the impact of material positioning during FSW dissimilar alloys, various studies have been performed in this regard. Dilip et al. [9] have performed the FSW of AA2219-T87 and AA5083-321 with the aim of performing the microstructural analysis of the joint. The weaker material (AA2219-T87) was positioned on the advancing side while the stronger material (AA5083-H321) was kept on the retreating side. The microstructural analysis revealed that the joint and the retreating side were dominated by the material which was placed on the advancing side (AA2219-T87). The microhardness value corresponding to the weaker material was observed on the retreating side where most tensile failure occurred.

Friction stir welding of the $3 \mathrm{~mm}$ thick AZ31B magnesium alloy and AA5052-H32 was performed by Taiki et al. [10]. The aluminium plate was positioned on the advancing side and magnesium $(\mathrm{Mg})$ plate on the retreating side during welding. There was a variation in welding speed and tool speed. The microstructure analysis revealed that the joint was dominated by the AA5052-H32. It was also noted from the microstructural analysis that the dominating AA5052 had refined grains compared to parent material although the hardness value dropped compared to AA5052-H32 base metal. Hardness distributions of the cross-section revealed that the intermetallic compounds (IMCs) partly existed in the stir zone (SZ). All the samples failed at the center of the joint during tensile tests analysis. This failure location showed that the joint was dominated by the material that was positioned on the advancing side during welding.

Cavaliere \& Panella, [11] conducted a study on the effect of tool position on fatigue properties of dissimilar $4 \mathrm{~mm}$ thick AA2024 and AA7075 plates joined by FSW. The AA2024 was positioned on 
the advancing side while AA7075 was kept on the retreating side. The joint attained when the tool was positioned $1 \mathrm{~mm}$ off the center (towards AA7075) had a higher hardness value compared to the joint attained when tool was $1.5 \mathrm{~mm}$ off the center of the weld. The maximum tensile properties of both joints were lower than the parent materials. Both joints revealed a ductile failure mode characterized by the presence of very fine dimples. The strong effect on fatigue crack growth was attributed to the positive fracture resistance $(\mathrm{Kr})$ value measured on the cross-section of the different welds.

Peng et al. [12] performed friction stir welded on the $5 \mathrm{~mm}$ AA5A06-H112 and AA6061-T651 plates. This welding was performed under controlled cooling conditions i.e., forced air cooling (FAC) and natural cooling (NC) conditions. The AA5A06-H112 was positioned on the advancing side while AA6061-T651 was kept on the retreating side. The $0.5 \mathrm{MPa}$ pressure was used to blow the air towards the welding direction which then intersected the surface of materials at angle of $30^{\circ}$. The microstructural analysis and microhardness test results for the joint produced under FAC were found to be higher compared to those that of the joint produced under NC condition. The tensile results for the joint produced under FAC condition were $10 \%$ higher than those produced at NC condition. The joint produced under NC condition had coarser grains compared to the joint produced under FAC condition. Both joints had ductile failure mode but the dimple size for the joint produced under FAC were higher than the joint produced under NC condition.

Shah et al. [13] investigated the influence of the tool eccentricity towards the friction stir welded dissimilar metals joint quality. They discovered that placing the stronger material on the advancing side improves the tensile strength and the percentage elongation of the joint. Their metallurgical analysis revealed that the tool eccentricity also plays a vital role towards the material flow however, there are some limitations when it comes to material mixing. The analysis of the joint formed when two dissimilar alloys are used in friction stir welding normally focuses on the mechanical properties. However, Giraud et al. [14] have gone to the extent of analyzing the compounds that are being formed during the FSW of dissimilar alloys. They have discovered that there are intermetallic compounds (IMCs) that are formed during the FSW of dissimilar alloys. These IMCs have a brittle nature which could lead to greater mechanical weakness.

Khodir and Shibayanagi [15] assessed the joint formed when AA2024-T3 was friction stir welded with AZ31 magnesium alloy. Their study involved the variation of welding speed at a constant rotational speed. The AA2024-T3 was located on the advancing side for all the welding. The microstructural analysis revealed that the increase in welding speed impacted the phase redistribution in the stir zone. The AA2024-T3 was distributed towards the lower regions of the stir zone while the AZ31 dominated the upper regions below the tool shoulder of the stir zone. The microstructural analysis also revealed a consistent formation of laminates structures in the SZ near the advancing side boundary between SZ and thermal affected zone (TMAZ) which were independent from welding speed variation. There were also intermetallic compounds that were formed in the SZ which contributed towards the fluctuation of the hardness distribution.

Rodriguez et al. [16] have friction stir welded AA6061-T6 and AA7050-T7451 with the purpose of assessing the microstructure and mechanical properties of the dissimilar welded joint. Their study involved the variation of rotational speed while keeping the welding speed constant. The AA7050-T7451 was positioned on the advancing side while AA6061-T6 was kept on the retreating side during welding. Tensile analysis revealed that the joints produced at lower speed were weaker than the base metals hence the fracture occurred at the SZ. The joints that were produced at higher rotational speed were stronger than AA6061-T6 base metal hence the fracture occurred consistently towards the AA6061-T6. The variation in fracture location was found to be directly linked with the material mixing at the SZ. The microstructural analysis revealed the ductile mode of failure. Moreover, the energy dispersive X-ray spectroscopy (EDS) results reveal the existence of three distinct layers where layer 1 had a nominal composition of AA6061, layer 2 had a composition of AA7050 and layer 3 had the combination of the two. Similar results were reported by Gou et al. [17] when they performed FSW on dissimilar AA6061-AA7075. 
Mofid et al. [18] performed a study on the friction stir welding of the 3-mm thick AZ31C-O magnesium alloy to AA5083 in air and under nitrogen liquid. Their study involved the tracking of the temperature profile during welding and they attained this through the installation of thermocouples. There was a notable decrease in IMCs formation for the joints produced under liquid nitrogen compared to joints produced through air. The X-ray diffraction (XRD) analysis results exhibited the intermetallic phases of $\mathrm{Al}_{3} \mathrm{Mg}_{2}, \mathrm{Al}_{12} \mathrm{Mg}_{17}$ and $\mathrm{Al}_{2} \mathrm{Mg}_{3}$. The stir zone of the welds produced under nitrogen atmosphere showed a smoother interface compared to welds produced through air atmosphere. The attained maximum temperature during the welding was $676 \mathrm{~K}$ and $651 \mathrm{~K}$ respectively during air weld and under water weld.

Friction stir welding of AA2024-T365 and AA5083-H111 was performed by El-Hafez and El-Megharbel [19]. Variation in process parameters and pin profiles were employed with the purpose of analyzing their influence to the microstructure and tensile properties. The stronger material (AA2024-T365) was positioned on the advancing side throughout the welding. The combination of the highest speeds of $1120 \mathrm{rpm}$ and $1400 \mathrm{rpm}$ with $80 \mathrm{~mm} / \mathrm{min}$ achieved the best strength and joint efficiency of $90 \%$ and this was due to sufficient heat being generated. Square pin profile produced higher strength joints compared to triangular and stepped profiles. Locating AA2024 on the advancing side (AS) played a significant role towards joint strength improvement. Cole et al. [20] also reported that the material placed on the advancing side dominates a major portion of the weld zone.

Vivekanandan et al. [21] used vertical milling machine for the friction stir welding of AA6035 and AA8011 with the aim of evaluating the mechanical properties of the dissimilar weld joint. The varying welding speed at a constant rotational speed was employed throughout the welding. The welds produced at the welding speed of $60 \mathrm{~mm} / \mathrm{min}$ were found to be the best results compared to other speed combinations. This parameter combination produced fine grains at the center of the weld which contributed to the increase in hardness value. The dissimilar friction stir welding of undiluted copper and AA1350 sheet with a thickness of $3 \mathrm{~mm}$ was investigated by Li et al. [22]. The AA1350 was placed on the advancing side throughout the welding performance. The microstructural results in the nugget zone showed the vortex-like pattern and lamella structure. There was no formation of IMCs in the nugget zone. The hardness dispersion revealed that the hardness on the copper side was higher than that on the AA1350 side and the hardness at the bottom of the nugget was generally higher than those previously mentioned. The tensile properties of the dissimilar welds were all lower than those of the base metals. A ductile-brittle mixed fracture surface was observed on the dissimilar joints of the tensile tested specimens.

Friction stir welding was applied on the $1.3 \mathrm{~mm}$ thick stiffened AA2024-T3 panels with the aim to analyze the crack growth behaviour [23]. The experimental tests were correlated to linear elastic finite element method and dual boundary element method (DBEM). It was found that the DBEM showed better results and accurate as the stress level increased as the crack was approaching the stiffener. A Similar study was conducted by Citarella et al. [24] using a hybrid technique to assess the fatigue performance of multiple cracked friction stir welded AA2024-T3 joints. The crack propagation experimental tests were evaluated using the contour method in order to analyze the distribution of the residual. The metallographic analysis results showed a visible initial defect which led to initial crack for the simulation. The experimental fracture surface confirmed the crack propagation. The numerical crack was comparable to fatigue area shown by the post- mortem fractography.

Sheng et al. [25] used friction stir welding technique to join the AA6005-T4 plates with the purpose of investigating the weldability, microstructure and mechanical properties of the said alloy. The microstructural analysis results showed recrystallized grains in the nugget zone with equiaxed grain sizes of about $2.2 \mu \mathrm{m}$. The maximum ultimate tensile strength of about $174 \mathrm{MPa}$ equivalent to $83.8 \%$ of the base material was obtained. A microhardness was reduced to $58 \mathrm{HV} 0.2$ by the dissolution of phase $\beta$. In another study, an impact of using a bobbin type tool in friction stir welding of AA6082-T6 plates at different rotational speeds was investigated [26]. This investigation involved the variation of tool rotational speed. The tensile strength was found to be increasing linearly 
with rotational speed. However, it was discovered that the tensile strength reached its maximum when the rotational speed of $800 \mathrm{rpm}$ was employed. The tensile strain of $7.9 \%$ was achieved at the same rotational speed. However, the strength and hardness were found to be having an inverse relationship with the increment of heat input at the speed beyond $800 \mathrm{rpm}$. The fractographic results showed a dimple fracture with white second phase particles of AlFeMnSi.

The $6 \mathrm{~mm}$ thick sheets of AA6061 and AA5086 were friction stir welded together to analyze the evolution of microstructure in the stir zone and its influence on tensile properties of the joints [27]. The welding parameters used were the rotational speed of $500 \mathrm{rpm}$, traverse speed of $35 \mathrm{~mm} / \mathrm{min}$ and the axial force of $4.9 \mathrm{kN}$. The tensile properties of the joints correlated with microstructural features and microhardness values. The dissimilar joint exhibited a maximum hardness of $115 \mathrm{HV}$ and a joint efficiency of $56 \%$ which was higher than the hardness of the base metals. This was attributed to the defect-free stir zone formation and grain size strengthening. Table 1 below give a tabulated review of the above literature. The idea behind the incorporation of this table is to show the typical positioning of the materials during welding of dissimilar materials and alloys. Table 1 also shows the mostly used tool material and tool profile in performing welding of dissimilar alloys/materials.

Table 1. Friction stir welding of dissimilar materials/alloys (RS-Retreating side, AS-Advancing side, SZ-Stir zone, TRS—Tool rotational speed, WS—Welding speed, El—Elongation, YS—Yield strength, JE-Joint efficiency, NS-Not specified.).

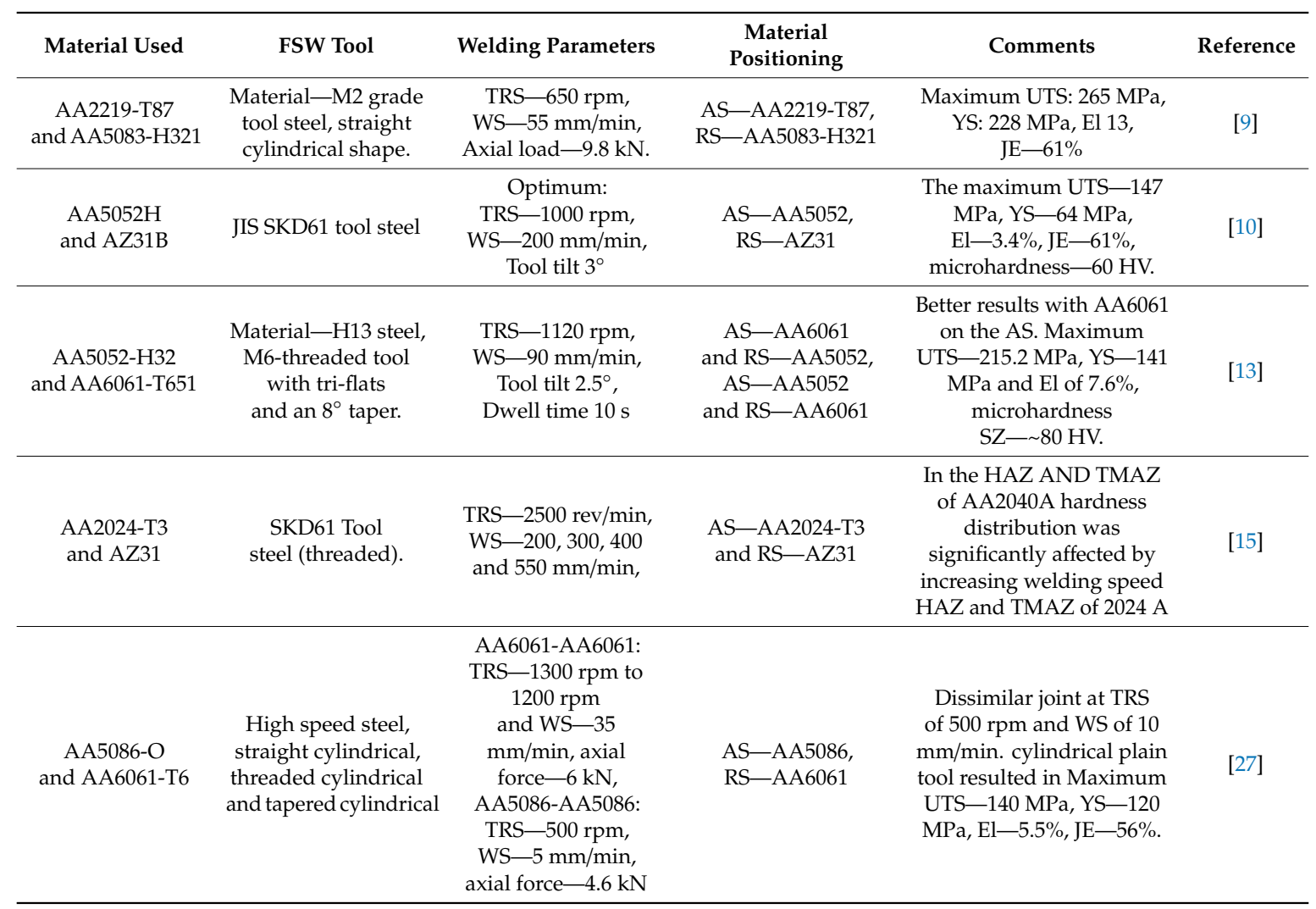

\subsection{TIG Welding of Similar and Dissimilar Alloys and Metals}

One of the most critical factor to consider for TIG welding is the filler metal, which mainly depends on the alloys to be welded. Ishak et al. [28] investigated the welding of dissimilar AA6061 and AA7075 using different filler metals, i.e., ER4043 (Si-reach) and ER5356 (Mg-reach). The depth analysis revealed that ER5356 penetrated deeper compared to the ER4043 and the depth of penetration plays an important role towards the strength of the weld or joint. The microstructural analysis revealed the existence of fusion zones that are normally identified on dissimilar TIG joints. The fusion zone (FZ) 
filled with ER5356 had finer grain sizes compared to the FZ filled with ER4043. Average hardness values for ER5356 filler specimens were higher compared to ER4043 filler specimens. TIG welding using the ER5356 filler yielded better joint compared to ER4043.

Borrisutthekul et al. [29] have evaluated the feasibility of using TIG welding technique in joining the dissimilar materials, i.e., steel plate and aluminium alloy plate. The microstructural analysis reveal that there was an existence of fusion zone (FZ) and heat affected zone (HAZ) which are the characteristics of the TIG welding. All the specimens were fractured on the same location during the tensile analysis, i.e., HAZ of aluminium alloy side. This type of behaviour was due to the growth of grain sizes that were observed through microstructural analysis. The existence of intermetallic reaction layers was also observed during the microstructural analysis.

Most studies that are studying different aspects of welding seem to be dominated by mostly two dissimilar aluminium alloys, i.e., AA5083 and AA6061 [30-35]. Waleed and Subbaiah [30] have evaluated the effect of using ER4047 filler rod in welding aluminium alloys AA5083-H111 and AA6061-T6. Similar analysis was also performed by other researchers with the focus on different aspects and different welding parameters on different grades of AA5083 [31-35]. Waleed and Subbaiah focused on analyzing the mechanical behaviour of the joint formed through the use of ER4047 filler rod. The tensile strength of the joint was lower than that of the base metals. The hardness value of the joint was varying in each side of the joint. This variation was caused by the formation of the magnesium-silicon $\left(\mathrm{Mg}_{2} \mathrm{Si}\right)$ precipitates on the AA6061 side. The microstructural analysis showed the elongation of grains towards the rolling direction. There was also an existence of cavities and micro-pores at the intersection point of the weld. There was a notable decrease in ductility and this decrease was caused by the presence of columnar grain.

In another study, the AA2195 was joined using the ultrasonic assisted TIG welding with the aim of analyzing the weld characteristics in terms of size and porosity [36]. It was found that the pores existed at the weld adjacent to the surface. The size of the porosity was found to increase with the decrease in welding speed. Additionally, the increase in ultrasonic power resulted to the decrease in weld porosity. Wang et al. [37] used the TIG welding technique to fabricate the AA7A05-T6/AA5A06-O dissimilar joint in order to study the mechanical properties of the said joint. The results revealed that the dissimilar joint had a tensile strength which was $78.8 \%$ and yield strength of $97.24 \%$ of the base metal (AA5A06-O). The elongation was about $84.29 \%$ to that of the base metal AA7A05-T6. The microstructural analysis results showed a coarse grain sizes due to high heat input which resulted in hardness and strength drop.

Narayanan et al. [38] have evaluated the impact of TIG welding parameter variation on the AA5083 joints. The welding current and the shielding gas flow rate were the two parameters that were being varied for the duration of the study. The tensile results and the hardness value for the joint was lower than that of the commercial base metal. The microstructural analysis showed that the grains in the HAZ region were coarser compared to the base metal hence the brittle failure. The welding quality improvement of AA6031 plates using an automated TIG welding system was performed by Mohan [39]. The mechanical analysis showed that the joint performance was found to be way lower than that of the base metal. There was an inverse proportionality observed between the welding speed and the tensile strength of the joint. There was also a variation of hardness value across the weld.

Automated pulse TIG welding using AA5083 and AA6061 dissimilar plates was performed by Baghel \& Nagesh, [40]. The main purpose was to evaluate the mechanical behaviour of the joint formed through this technique. The radiographical analysis revealed the presence of porosities which were caused by the lack of proper penetration. The tensile results for the joint were lower than the base metal. There was a variation of hardness value which was caused by non-uniformity of the grain sizes across the weld. The surface fracture exhibited the ductile failure mode. The impact of the welding speed variation towards the quality of the AA5083 TIG welded joints was analyzed by KumarSingh et al. [41]. All the other parameters were kept constant but only the welding speed that was varying. The tensile results showed a linear relationship with the welding speed until $100 \mathrm{~mm} / \mathrm{min}$. The notable decrease in 
tensile results was observed at the welding speed beyond $100 \mathrm{~mm} / \mathrm{min}$. The microstructure of the weld pool showed a refined grain size in comparison to the base metal.

TIG welding of dissimilar AA2014 and AA5083 was investigated by Sayer et al. [42]. One-sided TIG welding was applied with two passes. The microstructural analysis results in the weld region showed nonhomogeneous less equiaxed grain distribution with bigger diameters when compared to AA2014 and AA5083-O base metals. The grain size increase was said to be due to severe heat input. The tensile test results were lower than those of base metal. The tensile test specimens fractured in the welded region revealing brittle mode of failure. There was a variation in hardness across the weld with a sharp decrease at the center. This sharp decrease at the center was caused by the high silicon content in the filler material which dominated the center of the weld. Singh et al. [43] reported the mechanical properties of TIG welding at different parameters with and without the use of flux. The welding parameters used were all varied with the purpose of determining the optimal welding parameter combination. The variation of current effected the decrease in hardness value of the joint. The hardness values for joint formed with flux were higher compared to those formed without flux.

Dissimilar AA7075-T651 and AA6061-T6 plates were TIG welded with the aim of investigating the hardness of the center of the weld joint [44]. The Al-Si alloy filler wire type was used in performing all the welding. The maximum hardness value for the joint was found to be lower than that of the base metals. There were voids that were observed through microstructural analysis. Kumar et al. [45] also discovered that the use of pulsed current during TIG welding improves the mechanical properties of the welded joint in comparison to continuous current welded ones. This was found to be caused by the microstructural grain refinement which occurs in the fusion zone. Table 2 summarizes the mostly studied welding parameters during welding similar and dissimilar alloys/materials. It also shows the typical plates profile and filer wire used for different analysis.

Table 2. TIG welding of dissimilar materials/alloys. (WC-welding current, WS-welding speed, $Q$-gas flow rate, FZ-fusion zone, YS - yield strength, $V$-voltage, $F$-frequency, FW—filler wire, BM-base metal, UP—ultrasonic power, NS-not specified).

\begin{tabular}{|c|c|c|c|c|}
\hline Material Used & Thickness & Welding Parameters & Comments & Reference \\
\hline AA2195 & $2 \mathrm{~mm}$ & $\begin{array}{l}\text { Ultrasonic TIG welding } \\
\text { and ordinary TIG, } \\
Q-15 \mathrm{~L} / \mathrm{min}, \mathrm{WC}-70 \mathrm{~A}, \\
\mathrm{WS}-100 \text { to } 200 \mathrm{~mm} / \mathrm{min}, \\
\mathrm{UP}-0 \text { to } 40 \mathrm{~W}, \mathrm{~F}-35 \mathrm{kHz}\end{array}$ & $\begin{array}{l}\text { Porosity decreases with a decrease } \\
\text { in welding speed for normal TIG. } \\
\text { Porosity and pore size in UP TIG } \\
\text { first decrease and increase with } \\
\text { an increase in the UP. }\end{array}$ & [36] \\
\hline $\begin{array}{c}\text { AA5A06-O } \\
\text { and AA7A05-T6 }\end{array}$ & NS & $\begin{array}{c}\text { Butt joint TIG, FW-ER5356, } \\
\text { WC-260 A, V-25 V, } \\
\text { WS-200 mm/min, } \\
Q-24 \mathrm{~L} / \mathrm{min}, \\
\text { SG- } 99.99 \% \text { argon. }\end{array}$ & $\begin{array}{c}\text { The maximum UTS-78.87\% BM, } \\
\text { YS-97.24\% BM, El-84.29\% } \\
\text { of BM, JE-61\%, FZ had coarse } \\
\text { grains resulted to } 120 \mathrm{HV} \\
\text { microhardness. }\end{array}$ & [37] \\
\hline $\begin{array}{c}\text { AA2014 } \\
\text { and AA5083 }\end{array}$ & $5 \mathrm{~mm}$ & $\begin{array}{l}\text { V joint, } Q-10 \mathrm{~L} / \mathrm{min} \text {, } \\
\text { SG-argon, } V-14 \mathrm{~V} \text {, } \\
\text { WC-140 to } 150 \mathrm{~A} \text {, } \\
\text { FW-TAL } 4043\end{array}$ & $\begin{array}{l}\text { Maximum UTS-175 MPa, } \\
\text { YS-128 MPa and El of } 2.6 \% \text {, } \\
\text { microhardness SZ— 125 HV. }\end{array}$ & [42] \\
\hline $\begin{array}{l}\text { AA5083-O } \\
\text { and AA6061-T651 }\end{array}$ & $6.35 \mathrm{~mm}$ & $\begin{array}{c}60^{\circ} \text { groove weld joint, } \\
\text { FW-ER } 5356, \mathrm{SG}-\text { pure } \\
\text { argon, } V-13.2 \mathrm{~V} \text {, } \\
Q-6 \mathrm{~L} / \mathrm{min}, \\
\text { WS- } 155 \mathrm{~mm} / \mathrm{min}, \mathrm{WC}-105 \\
\text { to } 175 \mathrm{~A}, F-2 \mathrm{~Hz} .\end{array}$ & $\begin{array}{l}\text { FZ microhardness increased with } \\
\text { higher cooling rate, finer dimples, } \\
\text { higher YS and UTS. }\end{array}$ & [40] \\
\hline AA5083 & $3 \mathrm{~mm}$ & $\begin{array}{l}\text { Pulsed TIG, WC- } 118 \text { to } \\
134 \mathrm{~A}, \mathrm{WS}-90 \text { to } \\
105 \mathrm{~mm} / \mathrm{min}, Q-\text { of } 6 \text { to } \\
7 \mathrm{~L} / \mathrm{min}\end{array}$ & $\begin{array}{c}\text { Maximum UTS at WC-134 A, } \\
\text { with } Q-7 \mathrm{~L} / \mathrm{min} \\
\text { and WS-98 } \mathrm{mm} / \mathrm{min} . \text { Fused } \\
\text { welding seams. }\end{array}$ & [41] \\
\hline
\end{tabular}




\subsection{Friction Stir Processing of Similar/Dissimilar Alloys/Metals}

Friction stir processing is a fairly new material processing technique. This then suggests that there are many works that are still in progress focusing in different aspects of this new technique. This involves the processing of plates and welded joints. The evaluation of the mechanical properties of the friction stir processed dissimilar AA2024 and AA6061 welded joint was performed by Hameed et al. [46]. The friction stir processed joints used were formed through the use of FSW technique. The authors did the mechanical analysis of the processed joint in comparison with the unprocessed joints. The parameters used in performing the processing were similar to those used to perform FSW. The tensile properties of the processed joint were higher than the unprocessed joint. The hardness value for the processed joint was higher than the unprocessed joint. The microstructural analysis for processed joint reveal finer grain sizes compared to the unprocessed one.

Karthikeyan and Kumar, [47] studied the relationship between process parameters and mechanical properties of a single pass friction stir processed AA6063-T6 plate. Processing was performed at different axial forces, traverse speeds and tool rotational speeds. The tensile results revealed a linear relationship with the axial force than any other parameter used. The improvement in ductility was found to be linearly depending on the axial force than on the other parameters. The impact of applying the FSP on $6 \mathrm{~mm}$ AA6056-T4 plates was investigated by Hannard et al. [48]. It is well known that the ductility of each material plays a very crucial role towards the formability of the material and the chosen material is mostly used in forming different components and structures. Hannard et al. discovered that the ductility of the plate increased with the increase in number of processing pulses. The existence of pores from the base metal was suppressed completely by the increase in multi-pass FSP. The multi-pass FSP was found to be the method in breaking the intermetallic particles and to redistribute them homogenously. Hannard et al. work have proven that the proper processing of the material occurs when the multi-pass FSP is used.

Mazaheri et al. [49] have shown the capabilities of FSP in producing surface composites. This capability was tested when they used the FSP technique to produce the $\mathrm{A} 356 / \mathrm{A}_{2} \mathrm{O}_{3}$ surface composites. The microstructural analysis results of the $\mathrm{A} 356 / \mathrm{A}_{2} \mathrm{O}_{3}$ indicated that $\mathrm{A}_{2} \mathrm{O}_{3}$ particles were well distributed in the aluminium matrix, and good bonding was also observed. The nanoindentation technique revealed that the microhardness for $A 356 / \mathrm{A}_{2} \mathrm{O}_{3}$ and $\mathrm{A} 356-n \mathrm{~A}_{2} \mathrm{O}_{3}$ surface composites was higher than the samples processed without $\mathrm{A}_{2} \mathrm{O}_{3}$ particles and the as-received A356 material. A similar study was performed by Kalashnikova and Chumaevskii [50] where they used the FSP technique to develop surface composite between titanium carbide (TiC) and AA6082. The microhardness of the composite was found to be higher compared to the AA6082 metal. The tensile properties of the composite were found to be matching those of AA6082.

The effect of FSP on AA2024-T3 was studied by Hashim et al. [51]. The performance of the FSP was based on the pin-less cylindrical shoulder. The hardness results revealed that the application of FSP increased the hardness of the processed sample compared to the base material. There was also a notable increase in tensile properties of the processed sample compared to the base metal. The microstructural grain size was also refined compared to the base metal and this was found to be in correlation with tensile results.

The impact of FSP technique on the mechanical properties of cast Al-Si base alloy was analyzed by Tsai and Kao [52]. The tensile properties of cast AC8A alloy were improved after FSP, particularly the tensile elongation, which increased from $<1 \%$ to $15.4 \%$. FSP resulted in improvement of the tensile strength as the result of a combination of dissolution, coarsening and strengthening precipitates, which were attained by the FSP parameters. Jana et al. [53] investigated the FSP effect on fatigue behaviour of the cast Al-7Si-0.6 Mg alloy. The results showed five times improvement in fatigue life for a hypoeutectic Al-Si-Mg cast alloy. FSP eliminated the porosities and refined the silicon (Si) particles resulting in a decrease of the crack growth rate. In addition, FSP resulted in both break-ups of the dendritic microstructure and complex material mixing. 
Kurt et al. [54] performed FSP on the aluminium alloy AA1050 to improve respective mechanical properties. Samples were subjected to the various tool rotating and traverse rates with and without silicon carbide ( $\mathrm{SiC}$ ) powders. The optimum processing parameters that were found to give better results were the rotational speed of $1000 \mathrm{rpm}$ and traverse speed of $20 \mathrm{~mm} / \mathrm{min}$. The results revealed that FSP reduced the AA1050 grain size, which subsequently increased its hardness. A good dispersion of $\mathrm{SiC}$ was obtained and a good formation of composite layer. The hardness of the formed composite surfaces was improved significantly compared to that of base metal. Bending strength of the produced metal matrix composite was significantly higher than that of the processed specimen and untreated base metal.

The impact of using various chromium molybdenum (Cr-Mo) steel tool profiles in performing the FSP on AA2014 was studied by John et al. [55]. The hexagonal profile was found to be the best profile in producing good mechanical properties of the processed sample. The highest value for the hardness was also achieved through the hexagonal pin profile. The hexagonal pin profile was found to be suitable in producing highly refined grains compared to other profiles tested in the study. The influence of FSP on the microstructure and mechanical properties in terms of hardness for AA6061 sheet was investigated by Prakash and Sasikumar [56]. The cylindrical shaped high steel tool was employed in performing the multi-pass FSP. The microstructural evaluation reveal that the grain size of the processed specimens was $70 \%$ smaller than the base metal. There was also a linear relationship between the hardness value and the number of pulses used. The tensile properties were found to be linearly depending on the number of pulses used during FSP.

Sinhmar et al. [57] have analyzed comparatively the mechanical properties of the processed and unprocessed AA7039. The modified surfaces were characterized in respect to macrostructure, microstructure, hardness and tensile properties. The results showed an increase in ductility from about $13.5 \%$ to $23.6 \%$ while the ultimate and yield strength were adversely affected. The results showed higher ductility on the longitudinal direction than in traverse direction. The multi-pass friction stir processing produced higher hardness than the single pass one. Santella et al. [58] showed that FSP created a uniform distribution of broken second-phase particles of A319 and A356 and eliminated the coarse and heterogeneous structure of the alloys. The study was performed to assess the mechanical properties and reported that the tensile and fatigue behaviour of the material were improved with friction stir technique. The transmission electron microscopy (TEM) observations revealed the generation of a fine-grained structure of 5-8 $\mu \mathrm{m}$ for FSP A356. Furthermore, TEM examinations revealed that the coarse $\mathrm{Mg}_{2}$ Si precipitates in the as-cast A356 sample disappeared after FSP, indicating the dissolution of most of the $\mathrm{Mg}_{2} \mathrm{Si}$ precipitates during FSP. FSP was found to be generally beneficial for dissolution of precipitates and structure homogenization [59].

Wrought AA5059 was friction stir processed by Izadi et al. [60] with the purpose of finding the best tool profile suitable for such class of aluminium alloy. Amongst the profile tested, the 3-flat threaded pin profile outshine the profile in all aspects. The microstructural analysis revealed that the average grain sizes were about $1.24 \mu \mathrm{m}$ and this size was far less than the grains of the base metal. This grain size contributed towards the improvement of the microhardness. The yield strength and the ultimate tensile stress were also found to be higher than the base metal. The percentage elongation was also found to be higher than 25\%. Ni et al. [61] have used FSP to modify the surface of cast Mg-9Al-1Zn alloy. The processed specimens were found to be defect free with fine-grain microstructure dominated by fine $\beta-\mathrm{Mg} 17 \mathrm{Al} 12$ particles. The fatigue properties of the processed specimens were found to be higher than the base metal. The employment of FSP resulted to the transformation of quasi-cleavage fracture to dimple fracture. It was also found that the employment of FSP brought about the suppression of porosities and coarse $\beta$ particles.

Sakurada et al. [62] were the first to perform a study on underwater FSW on AA6061. Their results showed that it was possible to generate enough friction for processing even though the workpieces were underwater. The stirred region of the underwater weld joint showed a finer microstructure in comparison to the one exposed to room temperature air conditions. The hardness of the underwater 
specimens was found to be relatively higher than those of the room temperature based specimens. Hofmann \& Vecchio [63] studied the effect of submerging FSP on the grain size of AA6061-T6 compared to in air FSP. Their results showed that more grain refinement was attained under submerged conditions due to a faster cooling rate. They also demonstrated the feasibility of predicting the grain size of the processed specimens through the use of boundary migration model.

Zhang et al. [64] performed the joint analysis produced through the processing that was performed under water. They used variation in rotational speed in assessing the joint quality. They discovered that the fracture of the underwater joints was mostly dependent on the tool rotational speed. Their tensile analysis results showed a linear relationship with the rotational speed. Darras \& Kishta [65] investigated the friction stir processing of AZ31 magnesium alloy in normal and submerged conditions. There were three condition used in performing the analysis of the joints i.e., air, hot underwater and cold underwater. The grain size for the cold underwater specimens was relatively smaller than the specimens produced at other different conditions. The thermal results revealed that the highest peak temperature for weld was in air-based processing compared to the other conditions. The longest processing duration was found when the processing was performed on air. Sabari et al. [66] have performed similar study on different material and processing parameters. They reported that the higher temperature gradient (along transverse and longitudinal weld axis) and higher cooling rate in underwater friction stir welds were a result of uniform heat absorption capacity of water when compared to the air-cooled welds.

El-Danaf et al. [67] have used commercial AA5083 rolled plates in analyzing the impact of FSP towards the ductility and the grain size of the processed specimens. The microstructure analysis showed a fine grain and an average disorientation angle of about $24^{\circ}$. Ductility was enhanced with a factor ranging between 2.6 and 5 when compared to the base metal. The strain rate sensitivity of the processed material was 0.33 while for the base metal was 0.018. Akinlabi et al. [68] investigated the effect of the tool rotational and traverse speeds as well as the number of passes on tribological characteristics of the modified surfaces. The FSPed samples exhibited lower wear rates than the as-cast A390 hypereutectic Al-Si alloy. The wear rates were found to decrease by reducing the tool rotational speed while increasing the tool traverse speed. There was a notable inverse correlation between the wear rate and the number of FSP passes.

Toma et al. [69] investigated the effect of FSP tool cutting depth on the mechanical properties of AA6061-T6. The cylindrical tool without the pin was employed in performing this analysis. The hardness was found to be increasing with the increase in cutting depth. The engineering flaws granules became smaller and the size of these granules increased with cutting depth. The tensile properties of the processed specimens were found to be improving with the increase in cutting depth. Abrahams et al. [70] investigated the properties and microstructure of friction stir processed 7075-T651 using various tool designs. Trials were conducted on AA5005-H34 with the aim of determining the most suitable FSP tool design out of all the considered pin profiles. Fully recrystallized fine microstructure and a defect free processed zone were achieved through the use of some of the FSP pin profiles. The grain sizes were reduced from the initial $192 \mu \mathrm{m}$ pancake-like microstructure for AA5005-H34 base material to the range between 10 and $20 \mu \mathrm{m}$ in the processed regions. The similar behaviour was also observed on the case of AA7075-T651. The traverse speed had a greater influence on the microhardness and mechanical properties compared to the tool rotational speed. It was also discovered the traverse speed suppressed the precipitates free zones which have negative impact towards the mechanical properties of the material.

The effect of the processing parameters of friction stir processing on the microstructure and mechanical properties of AA6063 was performed by Zhao et al. [71]. Post FSP produced fine equiaxed $\alpha$-Al grains formed in the weld nugget of AA6063. The size of those $\alpha-\mathrm{Al}$ grains was increasing with the increase in rotational speed. Tunnel defects were observed in the TMAZ region for a low tool rotation speed. When the rotational speed exceeded $700 \mathrm{rpm}$, a good combination interface was formed between the weld nugget (WN) and the TMAZ. Electron backscatter diffraction results showed that the fraction of the high-angle grain boundary was increased after FSP in the WN. The TEM 
analysis results showed that the densities of needle-shaped precipitates were reduced in the WN. There was an observed linear relationship between the ultimate tensile strength (UTS) and the tool rotational speed.

Rouzebehani et al. [72] have used AA7075 plate to perform FSP underwater and room temperature with the purpose of analyzing the metallurgical and mechanical properties. The variable process parameters were used. The temperature during FSP was monitored and recorded using the K-type thermocouple placed underneath the plate close to the abutting line of the workpiece. The average grain and precipitate sizes of the weld nugget zones were significantly reduced by the submerged conditions. The best metallurgical and mechanical properties were achieved when the processing was performed under water. There are numerous attempts that are being reported where the FSP technique is being utilized to produce surface composite. These attempts look into different alloys of aluminium and different dopants. Singh et al. [73] have produced surface composite through the use of FSP technique. The approach used by Singh et al. was to deposit SiC particles inside the holes drilled on the surface of AA6063 plate. The microhardness of the fabricated composite was relatively high compared to the one for the base metal. It was discovered that the increase in microhardness was due to the pining effect of hard SiC particles. The good bonding between the SiC particles and AA6063 results to the improvement of tensile strength of the composite when compared with base metal.

The microstructural modification of AA206 through the use of FSP was also reported by Sun et al. [74]. This modification was performed so as to comparatively evaluate the mechanical properties of processed and unprocessed AA206 material. A $6.26 \mathrm{~mm}$ and $16 \mathrm{~mm}$ thick plates were used for tensile and fatigue test respectively. The two key processing parameters were tool rotation speed and tool traverse speed. The results showed an increase in both yield strength and UTS after FSP when compared to those of the base metal. There was a notable improvement in yield strength and UTS on the processed plates compared to the base material. The percentage of elongation and fatigue strength also increased compared to the unprocessed ones.

Thakral et al. [75] used FSP to enhance the tensile properties and hardness of the TIG welded AA6061-T6 joint. Tensile results showed that the average UTS value for the base metal was $299 \mathrm{MPa}$, $85 \mathrm{MPa}$ for the TIG welded joint and $125 \mathrm{MPa}$ for the friction stir processed (FSPed) TIG welded joint. An increase of $48 \%$ was reported on the UTS on the TIG welded joint. The hardness values of FSP TIG specimen ranged from 72-74 HV which was almost similar to that of base metal which was $74 \mathrm{HV}$ whereas in TIG specimen hardness value ranged from 66-68 HV. Microstructural analysis was performed on the weld zone to evaluate the effect of welding parameters on welding quality and grain structure. The microstructure of FSPed TIG joint showed very fine equiaxed recrystallized grains compared to the microstructure of TIG joint.

The effect of a single pass FSP on the mechanical properties and microstructure of the commercially pure aluminium was investigated by Yadav and Bauri [76]. The grain size of the FSPed specimens were way smaller than those of the base metal. The TEM results showed fine grains with well-defined boundaries. The tensile results showed UTS increase of about $25 \%$ while the ductility decreased by about $10 \%$. The impurity particles observed in TEM resulted in the yield strength decrease. The hardness also improved substantially compared to the base metal. Feng et al. [77] investigated the effect of SFSP on the microstructure of the AA2219 sheet. The grain size on the stir zone was less than that of the base metal (BM). The area fraction of the ultra-fine grains in the stir zone increased as heat input decreased. The results showed a decrease in microhardness of the SFSP stir zone compared to that of the unprocessed BM. The processed zone exhibited microhardness that was higher than that of the base metal.

The 6-mm thick aluminium alloy AA6082 was subjected to underwater FSP to test the changes in the UTS [78]. The high carbon high chromium steel rod of diameter $20 \mathrm{~mm}$ material was used as the processing tool for this investigation. The result revealed that the maximum tensile strength of the underwater joints was higher than that of the normal air. The effect of SFSP on the mechanical and microstructural properties of $10 \mathrm{~mm}$ thick AA7075 was investigated by Nourbakhsk and Atrian [79]. 
A thermocouple was used to record the temperature of water during the processing. The single pass FSP was used in carrying out the analysis. The results obtained from the submerged processing were similar to those obtained by other researchers [64,65,72]. Mabuwa and Msomi [80] used a single pass FSP to improve the mechanical properties of the TIG and friction stir welded AA5083-H111 joints. The processing was performed under normal room conditions. The FSPed joints showed better mechanical properties compared to the unprocessed ones. The DRX that happened during FSP resulted in ultra-fine grain refinement of the FSPed joints. Table 3 presents typical summary of the friction stir processed literature with the purpose of showing the mostly affected material property post friction stir processing. Table 4 shows different types of tool that are used on FSP extracted from cited literature. Figure 2 shows typical stress strain curves for the unprocessed and friction stir processed joints.

Table 3. Typical results of friction stir processed plate and joints. (TS-traverse speed, RTS—tool rotational speed, UTS—ultimate tensile strength, SZ—stir zone, NS—not specified.).

\begin{tabular}{|c|c|c|c|c|c|c|}
\hline Material Used & FSP Tool & Condition & Surface/Joint & $\begin{array}{l}\text { Processing } \\
\text { Parameters }\end{array}$ & Enhanced Property & Reference \\
\hline AA6063-T6 & NS & Normal & surface & $\begin{array}{l}\text { Optimum: TRS-1200 } \\
\text { and } 1400 \mathrm{rpm}, \\
\text { TS-40.2 } \mathrm{mm} / \mathrm{min}, \\
\text { axial force-10 kN }\end{array}$ & $\begin{array}{l}\text { UTS, ductility, } \\
\text { microhardness }\end{array}$ & [47] \\
\hline AA6061 & $\begin{array}{l}\text { EN } 31 \\
\text { steel }\end{array}$ & Normal & $\begin{array}{l}\text { TIG welded } \\
\text { joint }\end{array}$ & $\begin{array}{l}\text { TRS }-1200 \mathrm{rpm} \text {, } \\
\text { TS }-75 \mathrm{~mm} / \mathrm{min}\end{array}$ & UTS, microhardness & [75] \\
\hline Pure $\mathrm{Al}(99.2 \%)$ & M2 steel & Normal (air) & surface & $\begin{array}{l}\text { TRS-640 rpm, } \\
\text { TS- } 150 \mathrm{~mm} / \mathrm{min}\end{array}$ & $\begin{array}{c}\text { significant } \\
\text { improvement in } \\
\text { UTS and hardness. } \\
\text { Marginal } \\
\text { increase in ductility }\end{array}$ & [76] \\
\hline AA2219-T6 & $\begin{array}{l}\text { standard } \\
\text { tool steel }\end{array}$ & Submerged & Surface & $\begin{array}{l}\text { TRS }-600 \text { to } 800 \mathrm{rpm}, \\
\text { TS }-200 \mathrm{~mm} / \mathrm{min}, \\
\text { Tool tilt } 2.5^{\circ}\end{array}$ & $\begin{array}{l}\text { As the TRS increase } \\
\text { the SZ hardness } \\
\text { decreases; } \\
\text { Refinement } \\
\text { of grains. }\end{array}$ & [77] \\
\hline AA7075 & NS & $\begin{array}{c}\text { Submerged } \\
\text { and normal (air) }\end{array}$ & Surface & $\begin{array}{l}\text { TRS } 800 \text { and } 1250 \\
\text { rpm, TS and } 40 \\
\text { and } 63 \mathrm{~mm} / \mathrm{min}\end{array}$ & $\begin{array}{c}\text { Ductility; Tensile } \\
\text { strength; Uniform } \\
\text { grain sizes }\end{array}$ & [79] \\
\hline AA5083-H111 & $\begin{array}{l}\text { high-carbon } \\
\text { steel }\end{array}$ & Unsubmerged & $\begin{array}{l}\text { TIG joint, } \\
\text { FSW joint }\end{array}$ & $\begin{array}{c}\text { TRS }-1000 \mathrm{rpm} \\
\text { and TS }-30 \mathrm{~mm} / \mathrm{min} \\
\text { Tool tilt } 2^{\circ}\end{array}$ & $\begin{array}{l}\text { Ductility; Grain } \\
\text { sizes refined } \\
\text { and UTS }\end{array}$ & [80] \\
\hline
\end{tabular}

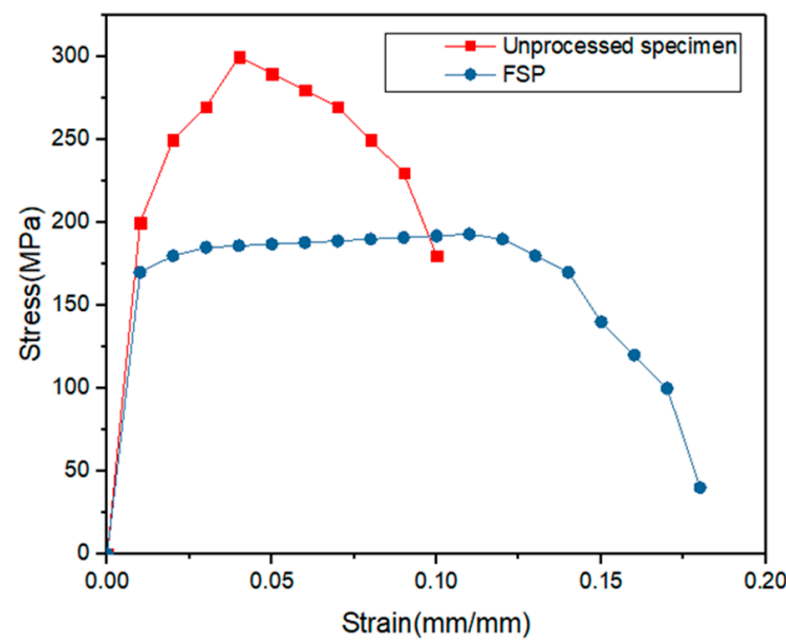

Figure 2. Tensile stress and strain curves for processed and unprocessed surface. 
Table 4. Typical FSP tools. (PL—Pin length, PD—Pin diameter, SD—Shoulder diameter, SL—Shoulder length, PH—Pin height, NS-Not specified, SBPL—Square base pin length, CHL-Conical head length).

\begin{tabular}{|c|c|c|c|c|}
\hline Material Processed & $\begin{array}{c}\text { Tool } \\
\text { Material }\end{array}$ & Tool Profile & Tool Dimensions & Reference \\
\hline A356 Aluminium & H13 steel & Threaded & $\begin{array}{l}\text { PL: } 4 \text { mm, PD: } 3.6 \mathrm{~mm} \text {, SD: } \\
18 \text { mm, SL: } 10 \mathrm{~mm} .\end{array}$ & [49] \\
\hline AC8A alloy & NS & NS & $\begin{array}{c}\mathrm{SD}-18 \mathrm{~mm}, \mathrm{PD}-5.2 \mathrm{~mm}, \\
\mathrm{PH}-2.7 \mathrm{~mm},\end{array}$ & {$[52]$} \\
\hline Cast F357 & NS & $\begin{array}{l}\text { Conical pin with } \\
\text { a stepped } \\
\text { spiral feature }\end{array}$ & $\begin{array}{l}\mathrm{PD}-4 \mathrm{~mm}, \mathrm{PH}-2 \mathrm{~mm}, \\
\mathrm{SD}-12 \mathrm{~mm},\end{array}$ & [53] \\
\hline AA6061-T6 & Alloy steel & Concave shoulder & $\mathrm{SD}-15 \mathrm{~mm}$ & [69] \\
\hline AA6063-T5 & H13 steel & Conical pin & $\begin{array}{c}\mathrm{SD}-18 \mathrm{~mm}, \mathrm{PL}-5.7 \mathrm{~mm} \\
\text { end PD-4 mm, Root } \\
\text { PD-6 mm, }\end{array}$ & {$[71]$} \\
\hline $\begin{array}{c}\text { AA7075-T651 } \\
\text { and AA5005-H34 }\end{array}$ & NS & $\begin{array}{l}\text { Square base pin with } \\
\text { conical head }\end{array}$ & $\begin{array}{c}\mathrm{PL}-3.2 \mathrm{~mm}, \mathrm{SD}-14 \mathrm{~mm} \\
\mathrm{PD}-3.6 \mathrm{~mm}, \mathrm{SBPL}-2.3 \\
\mathrm{~mm}, \mathrm{CHL}-3 \mathrm{~mm} .\end{array}$ & {$[70]$} \\
\hline \multirow{2}{*}{$\begin{array}{c}\text { AA7075-T651 } \\
\text { and AA5005-H34 }\end{array}$} & NS & Pyramid shape & PL-3.2 mm, PD-3 mm, & \multirow{2}{*}{ [70] } \\
\hline & NS & Conical threaded & $\mathrm{PL}-3.2 \mathrm{~mm}, \mathrm{PD}-3 \mathrm{~mm}$ & \\
\hline
\end{tabular}

\subsection{Advantages of Friction Stir Welding, TIG Welding and Friction Stir Processing}

Table 5 presents the advantages of the friction stir welding, TIG welding and friction stir processing techniques.

Table 5. Advantages of Friction stir welding, TIG welding and friction stir processing (IMC-intermetallic compounds, BM-base materials, UFG-ultra-fine grains, DR-dynamic recrystallization, El—elongation, YS—yield strength, UTS — ultimate tensile strength).

\begin{tabular}{|c|c|c|c|}
\hline Feature & Friction Stir Welding & TIG Welding & Friction Stir Processing \\
\hline $\begin{array}{l}\text { Microstructure } \\
\text { evolution }\end{array}$ & $\begin{array}{l}\text { uniform arrangement with } \\
\text { fine grains }[13-15,17,80] \text {. }\end{array}$ & $\begin{array}{c}\text { Nonhomogeneous, coarse } \\
\text { less equiaxed grain } \\
\text { distribution with bigger } \\
\text { diameters }[30,37,42,80] \text {. }\end{array}$ & $\begin{array}{l}\text { Thermal mechanical effects } \\
\text { and DRX during FSP results in } \\
\text { coarse grains transformation } \\
\text { to UFG. }[52,54,60,70,87-91] \text {. }\end{array}$ \\
\hline Microhardness & $\begin{array}{l}\text { Microhardness of the joint } \\
\text { increased when compared to } \\
\text { base BM ones [11,27]. } \\
\text { But remains circumstantially. }\end{array}$ & $\begin{array}{c}\text { Microhardness decreases } \\
\qquad[37-39] .\end{array}$ & $\begin{array}{c}\text { FSP resulted in an increase in } \\
\text { hardness when compared to } \\
\text { the unprocessed surface } \\
{[89,90,92,93] .}\end{array}$ \\
\hline $\begin{array}{l}\text { Tensile properties } \\
\text { (UTS, YS, El) }\end{array}$ & $\begin{array}{l}\text { Tensile properties are mostly } \\
\text { lower when welding } \\
\text { dissimilar alloys due to } \\
\text { the formation of IMC } \\
\text { (circumstantial) compared to } \\
\text { the BM ones }[10-13,15,21,94] .\end{array}$ & $\begin{array}{c}\text { Tensile properties decrease } \\
\text { compared to BM ones } \\
{[38,40,41] .}\end{array}$ & $\begin{array}{c}\text { FSP also improves the tensile } \\
\text { properties of a material } \\
{[54,56,68,87] \text {. Improved }} \\
\text { ductility of the processed } \\
\text { surface in comparison to } \\
\text { the unprocessed one }[80,95] \text {. }\end{array}$ \\
\hline
\end{tabular}




\subsection{Mostly Processed Welded Structures}

Based on the literature cited the most friction stir processing has been performed to enhance the properties of the base metal rather than welded joints. There are limited works $[46,60]$ reporting on processing the friction stir welded joints with only $[76,80]$ reported on using FSP as a post processing of the TIG and FSWed welded joints. No other searchable literature was obtained on post processing for both FSW and TIG welded joints. This then suggest that there are more opportunities of exploring the impact of employing FSP technique on TIG welded structures.

\subsection{Mostly Processed Grades}

The most processed aluminium alloy series based on the presented literature was 6xxx (AA6061, AA6082, AA6063, AA6056), with AA6061 taking a lead. Following the 6xxx was the 7xxx (AA7075, AA7039), 2xxx (AA2024, AA2219, AA2014) and the 5xxx (AA5005, AA5083, AA5059).

\section{Concluding Remarks}

In all the work that has been performed thus far, it has been noted that all the focus has been on FSP as an enhancement technique on aluminium alloys, magnesium, and other alloys. It is also noticed that the common mechanical properties analyzed include the tensile test, fatigue and microhardness. These properties are studied correlatively with the microstructure. Very few works thus far, which considers friction stir processing as a post weld processing technique for tungsten inert gas dissimilar alloy welded joint. There is minimal to no trace of any literature on submerged friction stir processing of tungsten inert gas and friction stir welded dissimilar alloy joints. Therefore, this opens an opportunity for the exploration on the impact of friction stir processing and submerged friction stir processing towards the properties of the friction stir welded and tungsten inert gas welded dissimilar joints.

Author Contributions: Both authors have fully contributed equally to all the work produced. All authors have read and agreed to the published version of the manuscript.

Funding: This research received no external funding.

Acknowledgments: The authors would like to thank the Cape Peninsula University of Technology for allowing this study to be performed.

Conflicts of Interest: The authors declare no conflict of interest. The authors declare there is no funding involved in this study.

\section{References}

1. Cam, G.; Kocak, M. Progress in joining of advanced materials. Int. Mater. Rev. 1998, 43, 1-44. [CrossRef]

2. Nicholas, E.D. Developments in the friction stir welding of metals. In Proceedings of the 6th International Conference on Aluminium Alloys, Toyohashi, Japan, 5-10 July 1998; pp. 139-151.

3. Patel, V.; Li, W.; Wang, G.; Wang, F.; Vairis, A.; Niu, P. Friction stir welding of dissimilar aluminum alloy combinations: State-of-the-art. Metals 2019, 9, 270. [CrossRef]

4. Sun, N. Friction Stir Processing of Aluminium Alloys. Master's Thesis, University of Kentucky, Lexington, KY, USA, 2009.

5. Marczyk, J.; Nosal, P.; Hebda, M. Effect of Friction Stir Processing on Microstructure and Microhardness of Al-TiC Composites. In Proceedings of the Student's Conference, Freiberg, Germany, 8-9 November 2018.

6. Węglowski, M.S. Friction stir processing-State of the art. Arch. Civ. Mech. Eng. 2018, 18, 114-129. [CrossRef]

7. Chaudhari, R.; Parekh, R.; Ingle, A. Reliability of Dissimilar Metal Joints Using Fusion Welding: A Review. In Proceedings of the International Conference on Machine Learning, Electrical and Mechanical Engineering (ICMLEME'2014), Dubai, UAE, 8-9 January 2014.

8. Simar, A.; Joncheere, C.; Deplus, K.; Pardoen, T.; de Meester, B. Comparing similar and dissimilar friction stir welds of 2017-6005A aluminium alloys. Sci. Technol. Weld. Join. 2013, 15, 254-259. [CrossRef] 
9. Dilip, J.J.S.; Koilraj, M.; Sundareswaran, V.; Janaki Ram, G.D.; Koteswara Rao, S.R. Microstructural characterization of dissimilar friction stir welds between AA2219 and AA5083. Trans. Indian Inst. Met. 2010, 63, 757-764. [CrossRef]

10. Morishige, T.; Kawaguchi, A.; Tsujikawa, M.; Hino, M.; Hirata, T.; Higashi, K. Dissimilar welding of Al and Mg alloys by FSW. Mater. Trans. 2008, 49, 1129-1131. [CrossRef]

11. Cavaliere, P.; Panella, F. Effect of tool position on the fatigue properties of dissimilar 2024-7075 sheets joined by friction stir welding. J. Mater. Process. Technol. 2008, 206, 249-255. [CrossRef]

12. Peng, G.; Yan, Q.; Hu, J.; Chen, P.; Chen, Z.; Zhang, T. Effect of forced air cooling on the microstructures, tensile strength, and hardness distribution of dissimilar friction stir welded AA5A06-AA6061 joints. Metals 2019, 9, 304. [CrossRef]

13. Shah, L.H.A.; Sonbolestan, S.; Midawi, A.R.H.; Walbridge, S.; Gerlich, A. Dissimilar friction stir welding of thick plate AA5052-AA6061 aluminum alloys: Effects of material positioning and tool eccentricity. Int. J. Adv. Manuf. Technol. 2019, 105, 889-904. [CrossRef]

14. Giraud, L.; Robea, H.; Claudina, C.; Desrayaud, C.; Bocherd, P.; Feulvarcha, E. Investigation into the dissimilar friction stir welding of AA7020-T651 and AA6060-T6. J. Mater. Process. Technol. 2016, 235, 220-230. [CrossRef]

15. Khodir, S.A.; Shibayanagi, T. Dissimilar friction stir welded joints between 2024-T3 aluminum alloy and AZ31 magnesium alloy. Mater. Trans. 2007, 48, 2501-2505. [CrossRef]

16. Rodriguez, R.I.; Jordon, J.B.; Allison, P.G.; Rushing, T.; Garcia, L. Microstructure and mechanical properties of dissimilar friction stir welding of 6061-To-7050 aluminum alloys. Mater. Des. 2015, 83, 60-65. [CrossRef]

17. Guo, J.F.; Chen, H.C.; Sun, C.N.; Bi, G.; Sun, Z.; Wei, J. Friction stir welding of dissimilar materials between AA6061 and AA7075 Al alloys effects of process parameters. Mater. Des. 2014, 56, 185-192. [CrossRef]

18. Mofid, M.A.; Abdollah-Zadeh, A.; Gürza, C.H. Investigating the formation of intermetallic compounds during friction stir welding of magnesium alloy to aluminum alloy in air and under liquid nitrogen. Int. J. Adv. Manuf. Technol. 2014, 71, 1493-1499. [CrossRef]

19. El-Hafez, H.A.; El-Megharbel, A. Friction stir welding: Dissimilar aluminum alloys. World J. Eng. Technol. 2018, 6, 408-419. [CrossRef]

20. Cole, E.G.; Fehrenbacher, A.; Duffie, N.A.; Zinn, M.R.; Pfefferkorn, F.E.; Ferrier, N.J. Weld temperature effects during friction stir welding of dissimilar aluminum alloys 6061-T6 and 7075-T6. Int. J. Adv. Manuf. Technol. 2014, 71, 643-652. [CrossRef]

21. Vivekanandan, P.; Arunachalam, V.P.; Prakash, T.; Savadamuthu, L. The experimental analysis of friction stir welding on aluminium composites. Int. J. Metall. Eng. 2012, 1, 1-6.

22. Li, X.; Zhang, D.; Qiu, C.; Zhang, W. Microstructure and mechanical properties of dissimilar pure copper/1350 aluminum alloy butt joints by friction stir welding. Trans. Nonferrous Met. Soc. China 2012, 22, 1298-1306. [CrossRef]

23. Sepe, R.; Armentani, E.; Di Lascio, P.; Citarella, R. Crack growth behavior of welded stiffened panel. Proc. Eng. 2015, 109, 473-483. [CrossRef]

24. Citarella, R.; Carlone, P.; Lepore, M.; Sepe, R. Hybrid technique to assess the fatigue performance of multiple cracked FSW joints. Eng. Fract. Mech. 2016, 62, 38-50. [CrossRef]

25. Sheng, X.; Li, K.; Wu, W.; Yang, W.; Liu, Y.; Zhao, Y.; He, G. Microstructure and mechanical properties of friction stir welded joint of an aluminum alloy sheet 6005A-T4. Metals 2019, 9, 1152. [CrossRef]

26. Li, Y.; Gong, W.; Sun, D. Effect of tool rotational speed on the microstructure and mechanical properties of bobbin tool friction stir welded 6082-T6 aluminum alloy. Metals 2019, 9, 894. [CrossRef]

27. Ilangovan, M.; Boopathy, S.R.; Balasubramanian, V. Microstructure and tensile properties of friction stir welded dissimilar AA6061-AA5086 aluminium alloy joints. Trans. Nonferrous Met. Soc. China 2015, 25, 1080-1090. [CrossRef]

28. Ishak, M.; Noordin, M.N.F.; Shah, L.H.A. Feasibility study on joining dissimilar aluminum alloys AA6061 and AA7075 by tungsten inert gas (TIG). J. Teknol. 2015, 75, 79-84. [CrossRef]

29. Borrisutthekul, R.; Mitsomwang, P.; Rattanachan, S.; Mutoh, Y. Feasibility of using TIG welding in dissimilar metals between steel/aluminum alloy. Energy Res. J. 2010, 1, 82-86.

30. Waleed, W.A.; Subbaiah, K. Effect of ER4047 filler rod on tungsten inert gas welding of AA5083-H111 and AA6061-T6 aluminium alloys. JCHPS 2017, 7, 210-213. 
31. Sefika, K. Multi-response optimization using the Taguchi based grey relational analysis: A case study for dissimilar friction stir butt welding of AA6082-T6/AA5754-H111. Int. J. Adv. Manuf. Technol. 2013, 68, 795-804.

32. Subbaiah, K.; Geetha, M.; Sridhar, N.; Koteswara Rao, S.R. Comparison of Tungsten Inert Gas and Friction Stir Welding of AA 5083-H321 Aluminium Alloy Plates. Trends in Welding Research. In Proceedings of the 9th International Conference, ASM International, Chicago, IL, USA, 4-8 June 2012.

33. Leitao, C.; Louro, R.; Rodrigues, D.M. Analysis of high temperature plastic behavior and its relation with weld ability in friction stir welding for aluminum alloys AA5083-H111 and AA6082-T6. Mater. Des. 2012, 37, 402-409. [CrossRef]

34. Menzemer, C.C.; Lam, P.C.; Wittell, C.F.; Srivarsan, T.S. A study of fusion zone microstructures of arc-welded joints made from dissimilar aluminum alloys. J. Mater. Eng. Perform. 2001, 10, 173-178. [CrossRef]

35. Palanivel, R.; Koshy Mathews, P.; Murugan, N. Optimization of process parameters to maximize ultimate tensile strength of friction stir welded dissimilar aluminum alloys using response surface methodology. J. Cent. South Univ. 2013, 20, 2929-2938. [CrossRef]

36. Chen, Q.; Ge, H.; Yang, C.; Lin, S.; Fan, C. Study on pores in ultrasonic-assisted TIG weld of aluminum alloy. Metals 2017, 7, 53. [CrossRef]

37. Wang, W.; Cao, Z.; Liu, K.; Zhang, X.; Zhou, K.; Ou, P. Fabrication and mechanical properties of tungsten inert gas welding ring welded joint of 7A05-T6/5A06-O dissimilar aluminum alloy. Materials 2018, 11, 1156. [CrossRef] [PubMed]

38. Narayanan, A.; Mathew, C.; Baby, V.Y.; Joseph, J. Influence of gas tungsten arc welding parameters in aluminium 5083 alloy. IJESIT 2013, 2, 269-277.

39. Mohan, P. Study the Effects of Welding Parameters on TIG Welding of Aluminum Plate. Master's Thesis, National Institute of Technology, Rourkela, India, 2014.

40. Baghel, P.K.; Nagesh, D.S. Mechanical properties and microstructural characterization of automated pulse TIG welding of dissimilar aluminum alloy. IJEMS 2018, 25, 147-154.

41. KumarSingh, S.; Tiwari, R.M.; Kumar, A.; Kumar, S.; Murtaza, Q.; Kumar, S. Mechanical Properties and Microstructure of Al-5083 by TIG. In Proceedings of the International Conference on Processing of Materials, Minerals and Energy, Ongole, India, 29-30 July 2018.

42. Sayer, S.; Yeni, C.; Ertugrul, O. Comparison of mechanical and microstructural behaviors of tungsten inert gas welded and friction stir welded dissimilar aluminum alloys AA 2014 and AA 5083. Kovove Mater. 2011, 49, 155-162. [CrossRef]

43. Singh, G.; Singh, F.; Singh, H. A Study of mechanical properties on TIG welding at different parameters with and without use of flux. IJTIR 2015, 16.

44. Patil, C.; Patil, H.; Patil, H. Experimental investigation of hardness of FSW and TIG joints of aluminium alloys of AA7075 and AA6061. Frat. Integrità Strutt. 2016, 10, 325-332. [CrossRef]

45. Kumara, S.T.; Balasubramanian, V.; Sanavullah, M.Y. Influences of pulsed current tungsten inert gas welding parameters on the tensile properties of AA 6061 aluminum alloy. Mater. Des. 2007, 28, 2080-2092. [CrossRef]

46. Hameed, A.M.; Resan, K.K.; Eweed, K.M. Effect of Friction Stir Processing Parameters on the Dissimilar Aluminum Alloys. In Proceedings of the ASME International Mechanical Engineering Congress and Exposition, Houston, TX, USA, 13-19 November 2015.

47. Karthikeyan, L.; Kumar, V.S. Relationship between process parameters and mechanical properties of friction stir processed AA6063-T6 aluminum alloy. Mater. Des. 2011, 32, 3085-3091. [CrossRef]

48. Hannard, F.; Castin, E.; Pardoen, T.; Mokso, T.; Maire, E.; Simar, A. Ductilization of aluminium alloy 6056 by friction stir processing. Acta Mater. 2017, 130, 121-136. [CrossRef]

49. Mazaheri, Y.; Karimzadeh, F.; Enayati, M.H. A novel technique for development of A356/Al2O3 surface nanocomposite by friction stir processing. J. Mater. Process. Technol. 2011, 211, 1614-1619. [CrossRef]

50. Kalashnikova, T.A.; Chumaevskii, A.V.; Rubtsov, V.E.; Ivanov, A.N.; Alibatyro, A.A.; Kalashnikov, K.N. Structural Evolution of Multiple Friction Stir Processed AA2024. In Proceedings of the International Conference on Advanced Materials with Hierarchical Structure for New Technologies and Reliable Structures (AMHS'17), Tomsk, Russia, 9-13 October 2017.

51. Hashim, F.A.; Salim, R.K.; Khudair, B.H. Effect of friction stir processing on (2024-T3) aluminum alloy. IJIRSET 2015, 4, 1822-1829. 
52. Tsai, F.; Kao, P. Improvement of mechanical properties of a cast Al-Si base alloy by friction stir processing. Mater. Lett. 2012, 80, 40-42. [CrossRef]

53. Jana, S.; Mishra, R.; Baumann, J.; Grant, G. Effect of friction stir processing on fatigue behavior of an investment cast Al-7Si-0.6 Mg alloy. Acta Mater. 2010, 58, 989-1003. [CrossRef]

54. Kurt, A.; Uygur, I.; Cete, E. Surface modification of aluminium by friction stir processing. J. Mater. Process. Technol. 2010, 211, 313-317. [CrossRef]

55. John, J.; Shanmuganatan, S.P.; Kiran, M.B.; Senthil Kumar, V.S.; Krishnamurthy, R. Investigation of friction stir processing effect on AA 2014-T6. Mater. Manuf. Process. 2019, 34, 159-176. [CrossRef]

56. Prakash, T.; Sasikumar, P. The Influences of the friction stir processing on the microstructure and hardness of AA6061 aluminium sheet metal. JMET 2013, 1, 66-72.

57. Sinhmar, S.; Dwivedi, D.K.; Pancholi, V. Friction Stir Processing of AA 7039 Alloy. In Proceedings of the International Conference on Production and Mechanical Engineering, Bangkok, Thailand, 30-31 December 2014.

58. Santella, M.L.; Engstrom, T.; Storjohann, D.; Pan, T.Y. Effects of friction stir processing on mechanical properties of the cast aluminum alloys A319 and A356. Scr. Mater. 2005, 53, 201-206. [CrossRef]

59. Kuncická, L.; Král, P.; Dvorák, J.; Kocich, R. Texture evolution in biocompatible Mg-Y-Re alloy after friction stir processing. Metals 2019, 9, 1181. [CrossRef]

60. Izadi, H.; Nolting, A.; Munro, C.; Gerlich, A.P. Effect of Friction Stir Processing Parameters on Microstructure and Mechanical Properties of AL 5059. In Proceedings of the 9th International Conference on Trends in Welding Research, Chicago, IL, USA, 4-8 June 2012.

61. Ni, D.R.; Wang, D.; Feng, A.H.; Yao, G.; Ma, Z. Enhancing the high-cycle fatigue strength of Mg-9Al-1Zn casting by friction stir processing. Scr. Mater. 2009, 61, 568-571. [CrossRef]

62. Sakurada, D.; Katoh, K.; Tokisue, H. Underwater Friction welding of 6061 aluminum alloy. JILM 2002, 52, 2-6. [CrossRef]

63. Hofmann, D.C.; Vecchio, K.S. Thermal history analysis of friction stir processed and submerged friction stir processed aluminum. MSEA 2007, 465, 165-175. [CrossRef]

64. Zhang, H.J.; Liu, H.J.; Yu, L. Microstructure and mechanical properties as a function of rotation speed in underwater friction stir welded aluminum alloy joints. Mater. Des. 2011, 32, 4402-4407. [CrossRef]

65. Darras, B.; Kishta, E. Submerged friction stir processing of AZ31 Magnesium alloy. Mater. Des. 2013, 47, 133-137. [CrossRef]

66. Sabari, S.S. Evaluation of Performance of Friction Stir Welded AA2519-T87 Aluminium Alloy Joints. Ph.D. Thesis, Annamalai University, Tamil Nadu, India, 1 September 2016.

67. El-Danaf, E.A.; El-Rayes, M.M.; Soliman, M.S. Friction stir processing: An effective technique to refine grain structure and enhance ductility. Mater. Des. 2010, 31, 1231-1236. [CrossRef]

68. Akinlabi, E.T.; Mahamood, R.M.; Akinlabi, S.A.; Ogunmuyiwa, E. Processing parameters influence on wear resistance behaviour of friction stir processed Al-TiC composites. Adv. Mater. Sci. Eng. 2014, 2014, 724590. [CrossRef]

69. Toma, E.; Karash, B.Y.; Saeed, R.; Taqi, M.; Qasim, E. The effect of the cutting depth of the tool friction stir process on the mechanical properties and microstructures of aluminium alloy 6061-T6. AJMA 2015, 3, 33-41.

70. Abrahams, R.; Mikhail, J.; Fasihi, P. Effect of friction stir process parameters on the mechanical properties of 5005-H34 and 7075-T651 aluminium alloys. Mater. Sci. Eng. 2019, 751, 363-373. [CrossRef]

71. Zhao, H.; Pan, Q.; Qin, Q.; Wu, Y.; Su, X. Effect of the processing parameters of friction stir processing on the microstructure and mechanical properties of 6063 aluminum alloy. Mater. Sci. Eng. 2019, 751, 70-79. [CrossRef]

72. Rouzbehani, R.; Kokabi, A.H.; Sabet, H.; Paidar, M.; Ojo, O.O. Metallurgical and mechanical properties of underwater friction stir welds of Al7075 aluminum alloy. J. Mater. Process. Technol. 2018, 262, 239-256. [CrossRef]

73. Singh, I.; Singh, T.; Singh, R.; Singh, S.G. Fabrication of AA-6063/Sic composite material by using friction stir processing. IJAR 2017, 5, 1652-1656. [CrossRef]

74. Sun, N.; Jones, W.J.; Apelian, D. Friction stir processing of aluminum alloy A206: Part II-Tensile and fatigue properties. Int. J. Met. 2019, 13, 244-254. [CrossRef]

75. Thakral, R.; Sanjeev, S.; Taljeet, S. Experimental analysis of friction stir processing of TIG welded aluminium alloy 6061. IJIRST 2018, 4, 51-57. 
76. Yadav, D.; Bauri, R. Effect of friction stir processing on microstructure and mechanical properties of aluminium. MSEA 2012, 539, 85-92. [CrossRef]

77. Feng, X.; Liu, H.; Lippold, J.C. Microstructure characterization of the stir zone of submerged friction stir processed aluminum alloy 2219. Mater. Charact. 2013, 82, 97-102. [CrossRef]

78. Singh, H.; Kumar, P.; Singh, B. Effect of under surface cooling on tensile strength of friction stir processed aluminium alloy 6082. AJEAT 2016, 5, 40-44.

79. Nourbakhsh, S.H.; Atrian, A. Effect of submerged multi-pass friction stir process on the mechanical and microstructural properties of Al7075. J. Stress Anal. 2017, 2, 51-56.

80. Mabuwa, S.; Msomi, V. Effect of friction stir processing on gas tungsten arc welded and friction stir welded 5083-H111 aluminium alloy joints. Adv. Mater. Sci. Eng. 2019, 2019, 3510236. [CrossRef]

81. Dawood, H.I.; Mohammed, K.S.; Raja, M.Y. Advantages of the Green Solid State FSW over the Conventional GMAW Process. Adv. Mater. Sci. Eng. 2014, 2014, 105713. [CrossRef]

82. Bevilacqua, M.; Ciarapica, P.E.; D’Orazio, A.; Forcellese, A.; Simoncini, M. Sustainability analysis of friction stir welding of AA5754 sheets. Procedia CIRP 2017, 62, 529-534. [CrossRef]

83. Nandan, R.; DebRoy, T.; Bhadeshia, H.K.D.H. Recent advances in friction-stir welding-Process, weldment structure and properties. Prog. Mater. Sci. 2008, 53, 980-1023. [CrossRef]

84. Shukla, R.K.; Shah, P.K. Comparative study of friction stir welding and tungsten inert gas welding process. IJST 2010, 3, 667-671.

85. Nicholas, E.D.; Kallee, S.W. Friction stir welding-a decade on. In Proceedings of the IIW Asian Pacific International Congress, Sydney, Australia, 29 October-2 November 2000.

86. Costa, M.I.; Verdera, D.; Vieira, M.T.; Rodrigues, D.M. Surface enhancement of cold work tool steels by friction stir processing with a pinless tool. Appl. Surf. Sci. 2014, 296, 214-220. [CrossRef]

87. Li, K.; Liu, X.; Zhao, Y. Research status and prospect of friction stir processing technology. Coatings 2019, 9, 129. [CrossRef]

88. Wang, L.Q.; Xie, L.C.; Lv, Y.T.; Zhang, L.C.; Chen, L.Y.; Meng, Q.; Qu, J.; Zhang, D.; Lu, W.J. Microstructure evolution and superelastic behavior in Ti-35Nb-2Ta-3Zr alloy processed by friction stir processing. Acta Mater. 2017, 131, 499-510. [CrossRef]

89. Sun, P.; Wang, K.; Wang, W.; Zhang, X. Influence of process parameter on microstructure of AZ31 magnesium alloy in friction stir processing. Hot Work. Technol. 2008, 37, 99.

90. Thompson, B.; Doherty, K.; Su, J.; Mishra, R. Nano-sized grain refinement using friction stir processing. In Friction Stir Welding and Processing VII; Springer: Cham, Switzerland, 2013; pp. 9-19.

91. Xin, R.L.; Zheng, X.; Liu, Z.; Liu, D.; Qiu, R.S.; Li, Z.Y.; Liu, Q. Microstructure and texture evolution of an Mg-Gd-Y-Nd-Zr alloy during friction stir processing. J. Alloy. Compd. 2016, 659, 51-59. [CrossRef]

92. Han, J.Y.; Chen, J.; Peng, L.M.; Zheng, F.Y.; Rong, W.; Wu, Y.J.; Ding, W.J. Influence of processing parameters on thermal field in Mg-Nd-Zn-Zr alloy during friction stir processing. Mater. Des. 2016, 94, 186-194. [CrossRef]

93. Khodabakhshi, F.; Gerlich, A.P.; Svec, P. Fabrication of a high strength ultra-fine grained Al-Mg-SiC nanocomposite by multi-step friction-stir processing. Mater. Sci. Eng. A 2017, 698, 313-325. [CrossRef]

94. Msomi, V.; Mbana, N.; Mabuwa, S. Microstructural analysis of the friction stir welded 1050-H14 and 5083-H111 aluminium alloys. Mater. Today Proc. 2019. [CrossRef]

95. Raj, K.H.; Sharma, R.H.; Singh, P.; Dayal, A. Study of friction stir processing (FSP) and high pressure torsion (HPT) and their effect on mechanical properties. Proc. Eng. 2011, 10, 2904-2910. [CrossRef]

(C) 2020 by the authors. Licensee MDPI, Basel, Switzerland. This article is an open access article distributed under the terms and conditions of the Creative Commons Attribution (CC BY) license (http://creativecommons.org/licenses/by/4.0/). 